\title{
Seed Yield and Some Agricultural Traits of Cowpea (Vigna unguiculata L. Walp.) Grown with Different Densities as a Double Crop
}

\author{
Mehmet Can ${ }^{1, a}$, İknur Ayan ${ }^{1, b, *}$, Hussein Abdulkadir Omar ${ }^{2, c}, Z_{\text {Zeki Acar }}^{1, d}$, Gülcan Kaymak ${ }^{1, e}$, Hanife Mut $^{3, f}$ \\ ${ }^{I}$ Department of Field Crops, Faculty of Agriculture, Ondokuz Mayis University, 55270 Samsun, Turkey \\ ${ }^{2}$ Faculty of Agriculture, Zamzam University of Science and Technology, Mogadishu, Somali \\ ${ }^{3}$ Department of Field Crops, Faculty of Agriculture and Natural Science, Bilecik Şeyh Edebali University, 11000 Bilecik, Turkey \\ *Corresponding author
}

\begin{tabular}{|c|c|}
\hline A R T I C L E I N F O & A B S T R A C T \\
\hline $\begin{array}{l}\text { Keywords: } \\
\text { Cowpea } \\
\text { Row Space } \\
\text { Double Crop } \\
\text { Seed Yield }\end{array}$ & $\begin{array}{l}\text { In addition to the good adaptation of high temperatures and poor soils, cowpea (Vigna unguiculata } \\
\text { L.) can be a good source of forage for livestock. This study was carried out to determine seed yield } \\
\text { and some agronomical parameters of cowpea grown in different row spaces as double crop in } \\
\text { Samsun ecological conditions. In the experiment, forage cowpea cultivar Ulkem and Line H- } 8 \\
\text { grown in four row spaces }(20,35,50,65 \mathrm{~cm} \text { ) in a Randomized Split Block Design with three } \\
\text { replications. Seeds were sowed after harvesting wheat at July } 13,2017 \text { and } 15 \mathrm{July} 2018 \text {. Seed } \\
\text { harvest was made at October } 20,2017 \text { and November } 5,2018 \text {. The results showed that seed yields } \\
\text { ranged from } 765 \text { to } 2178 \mathrm{~kg} \mathrm{ha}-1 \text { in } 2017 \text { and } 397 \text { to } 1464 \mathrm{~kg} \mathrm{ha}^{-1} \text { in } 2018.1000 \text { seed weight ranged } \\
\text { from } 161.17 \text { to } 183.93 \mathrm{~g} \text { in } 2017 \text { and } 146.40 \text { to } 160.90 \mathrm{~g} \text { in } 2018 \text {. In } 2017 \text { and } 2018 \text {, mature pod } \\
\text { ratio were } 65.7-85.8,30.0-60.3 \% \text { respectively. Pod number per plant was between } 5.66-15.00 \\
\text { pods/plant in } 2017,9.50-16.25 \text { pods/plant in } 2018 \text {. Seed number per pod was ranged from } 8.80 \text { to } \\
12.43 \text { seeds/pod in } 2017 \text {, from } 8.00 \text { to } 11.50 \text { seeds/pod in } 2018 \text {. Though the highest seed yields } \\
\text { were obtained from } 20 \mathrm{~cm} \text { row space, it is risky cultivated cowpea for seed production as double } \\
\text { crop in Samsun conditions because of earlier autumn rainfall and high humidity. }\end{array}$ \\
\hline
\end{tabular}

Mature pod ratio crop in Samsun conditions because of earlier autumn rainfall and high humidity.

\begin{tabular}{|c|c|c|c|}
\hline $\begin{array}{l}\text { zir.mehmet@gmail.com } \\
\text { xusni015@gmail.com } \\
\text { gulcankaymak92@gmail.com }\end{array}$ & $\begin{array}{l}\text { (iD) } h t t p: / / o r c i d . o r g / 0000-0003-0230-6209 \\
\text { (iD) } h t t p: / / \text { orcid.org/0000-0002-0805-9272 } \\
\text { (iD) } h t t p: / / \text { orcid.org/0000-0002-0915-0529 }\end{array}$ & $\begin{array}{l}\text { b@ilknuray@omu.edu.tr } \\
\text { d@zekiacar@omu.edu.tr } \\
\text { f@ hanife.mut@bilecik.edu.tr }\end{array}$ & $\begin{array}{l}\text { (iD) } h t t p: / / / o r c i d . o r g / 0000-0002-5097-9013 \\
\text { (i) } h t t p: / / o r c i d . o r g / 0000-0002-0484-1961 \\
\text { (iD } h t t p: / / o r c i d . o r g / 0000-0002-5814-5275\end{array}$ \\
\hline
\end{tabular}

\section{Introduction}

The cowpea (Vigna unguiculata L.) is an important legume widely cultivated in tropics and subtropics for forage, green pods and grains (Ali et al., 2004). Cowpea is usually better adapted to drought, high temperatures and other biotic stresses compared with other crops (Kuykendall et al., 2000; Martins et al., 2003). However, the growth and development of many cowpea cultivars are affected by drought and high temperatures, especially during floral development (Dadson et al., 2005). The biggest technical constraint in livestock production in Turkey is forage deficiency especially during the summer period when pasture vegetation is dry. So there is a need for new warm-season forages to fill the forage gap in this period. Cowpea hay is a nutritious balanced fodder for animals (Singh et al., 2003) and has a great function in feeding animals. Having a high nutritive value of green forage cowpea, hay contains $14-21 \%$ crude protein, while the seeds have the rate of $18-26 \%$ crude protein. It was stated that cowpea is grown alone for forage yield. However, it could be grown mixed with maize, sorghum and millets for silage (Ismail and Hall, 2000; Basaran et al., 2011; Ayan et al., 2012). Cowpea can be grown as the main crop or double crop for the aim of forage production in agricultural system in Turkey. The aim of this study is to determine the forage yield and some agricultural traits of cowpea grown as double crop with different row spacing in the ecological conditions of Samsun.

\section{Materials and methods}

The study was carried out according to factorial design at randomized blocks with 3 replicates in Samsun (Turkey) ecological conditions in 2017 and 2018. In the experiment, Cv. Ulkem and Line H-8 were grown with four different 
row spaces $(20,35,50,65 \mathrm{~cm})$. The texture experimental area was clay (56.3), organic matter was medium (2.68), $\mathrm{pH}$ nötr (6.89), $\mathrm{P}_{2} \mathrm{O}_{5}$ content good $(22.89 \mathrm{~kg} / \mathrm{da})$ and without salt (0.52). Throughout the vegetation period (from July to October) of 2017 and 2018 total rainfall were 77.5 and $283.6 \mathrm{~mm}$, mean temperature was $22.1^{\circ} \mathrm{C}$ and $22.9^{\circ} \mathrm{C}$, average relative humidity was $63.68 \%$ and $65.2 \%$. Climate diagrams are given in Figures 1 and 2 that related to precipitation and temperature in 2017 and 2018. Cowpea seeds were sown after harvesting wheat crop in the mid of July and the harvest were made 20 October in 2017 and 30 October 2018. Irrigation process was made 5 times in 2017 and 3 times in 2018. In the study seed yield, mature pod ratio, 1000 seed weight, pod number per plant, seed number per pod were investigated. All data obtained from this study was analysed by using SPSS 25.0 program. The differences amongst the mean values were calculated according to Duncan test.

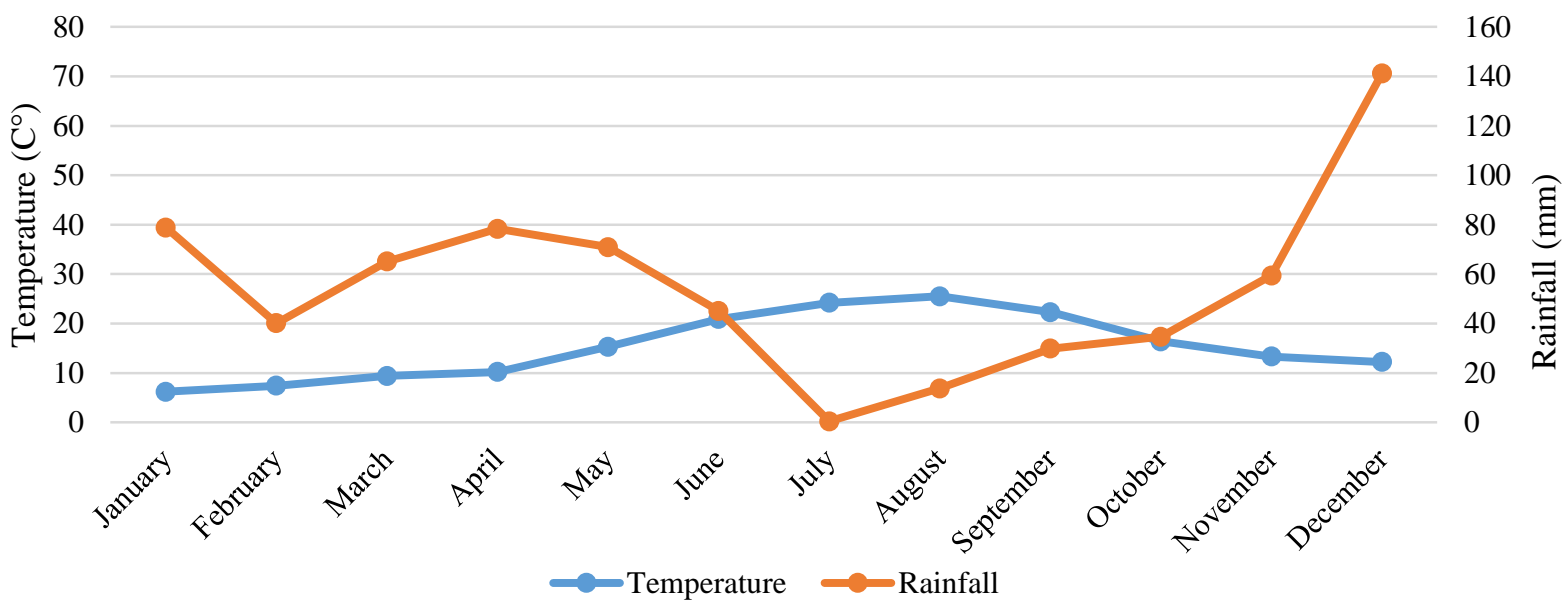

Figure 1. Climatic diagram of Samsun in 2017

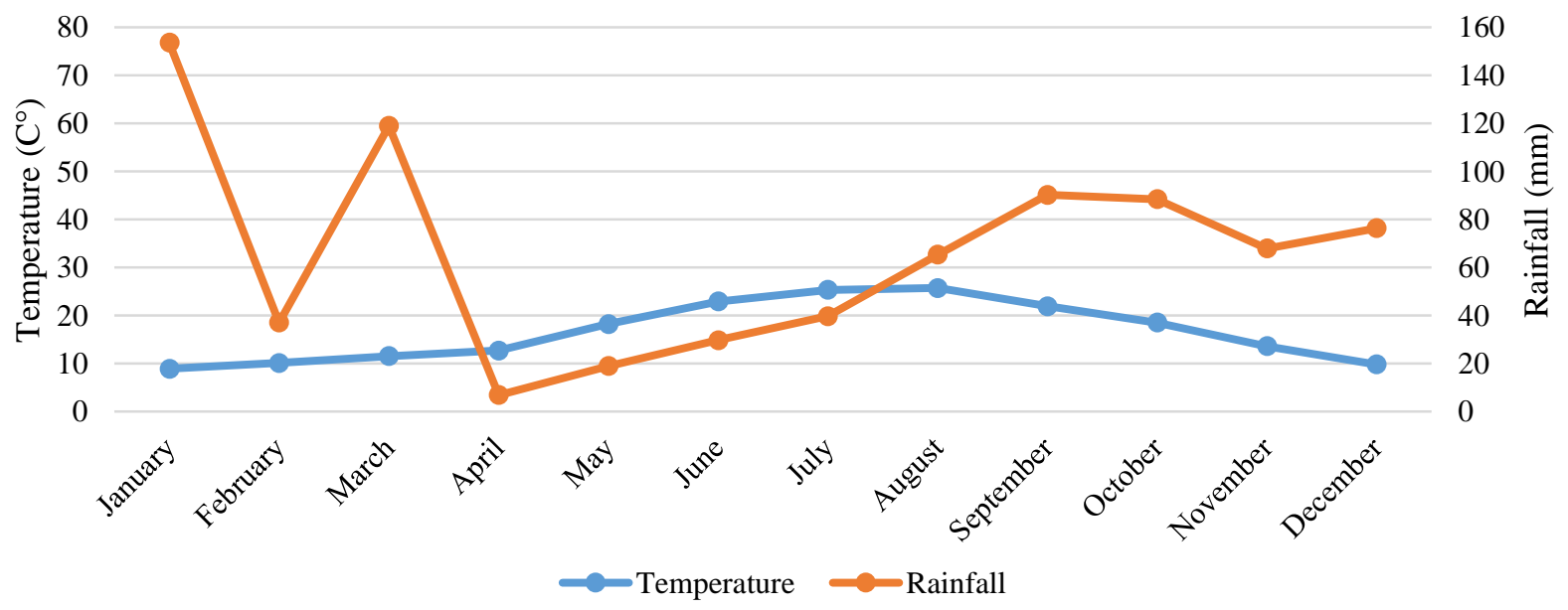

Figure 2. Climatic diagram of Samsun in 2018

\section{Results and Discussion}

\section{Seed Yield and 1000-Seed Weight}

Regard the seed yield, significant differences were determined between genotypes and row spaces both 2017 and 2018. The highest seed yield was obtained from $\mathrm{Cv}$. Ulkem grown with $20 \mathrm{~cm}$ row space both 2017 and 2018 as 2179 and $1464 \mathrm{~kg} \mathrm{ha}^{-1}$, respectively (Table 1). As the mean of row spaces, $\mathrm{Cv}$. Ulkem gave higher seed yield than those of the Line H-8. Wider row spaces caused decreasing of seed yield for both genotypes. Seed yield was higher due to the presence of more plants in the unit area in $20 \mathrm{~cm}$ row spacing. Seed yields were lower in 2018 compare to 2017 (Figure 3). In 2018, during the seed ripening period, both precipitation and higher temperatures encouraged plants to grow vegetatively. Consequence of this, pod ripening rate and seed yield was decreased (Figures 1 and 2; Table 2).
Some previous studies seed yield of cowpea was determined between 751-1420 kg ha-1 (Peksen and Artik, 2004; Basaran et al, 2011). Ozturan and Gulumser (2004), obtained the highest seed yield $\left(2731 \mathrm{~kg} \mathrm{ha}^{-1}\right)$ from the lowest $825 \mathrm{~cm}$ ) row space when cowpea grown as main crop in Samsun conditions. A thousand seed weight of $\mathrm{Cv}$. Ulkem was higher than the Line H-8 in both years. While the effect of row spaces on 1000 seed weight was significant in 2017, it was insignificant in 2018 (Table 1). Genotypes, environmental conditions, main or double crop conditions can be easily effected on 1000 seed weight of cowpea (Atis, 2000; Basaran et al, 2011). Those researchers were determined 1000 seed weight of cowpea as $129.3-233.2 \mathrm{~g}$. 


\section{Mature Pod Ratio, Pod and Seed Numbers}

Some of the pods were immature at the harvest time, because the experiment was carried out in double crop conditions. Mature and immature pods weighed up separately in order to calculate mature pod ratio. In terms of mature pod ratio, there were significant differences between the genotypes and row spaces in both years. $\mathrm{Cv}$. Ulkem gave higher mature pod ratio than those of the Line $\mathrm{H}-8$ in both years. Mature pod ratio of $\mathrm{Cv}$. Ulkem were 80.9 and $55.3 \%$, respectively in 2017 and 2018. In general, mature pod ratio decreased as row spacing expanded (Table 2). As reflects of mature and immature pod yields, $\mathrm{Cv}$. Ulkem had higher mature pod ratio in both years. Mature pod yield and ratio totally depends on genotype and environmental conditions. Thus, as the result of suitable conditions mature pod ratio of $\mathrm{Cv}$. Ulkem was reached to $85.8 \% 20 \mathrm{~cm}$ row spacing in 2017. Regard to pod number per plant, significant differences were determined between genotypes in 2017 and amongst the row spacing in both years. Cv. Ulkem has more pod number as average of 10 than the Line $\mathrm{H}-8$ in 2017 , but average pod number of the Line $\mathrm{H}-8$ has reached to 12.63 and exceeded to $\mathrm{Cv}$. Ulkem in 2018. Though differences were significant, according to the row spacing variation of the figures was not consistent (Table 2). Pod number of cowpea was varied between 9 and19 in some previous studies (Gulumser et al, 1989; Ozturk, 2010). Consider the seed number little variation was determined between the genotypes and row spacing. Mean seed number was 9-11 in per pod (Table 2).

Table 1. Seed yield and 1000-seed weight of cowpea*

\begin{tabular}{c|ccccc}
\hline \multirow{2}{*}{ Genotypes } & \multirow{2}{*}{ Row Spaces $(\mathrm{cm})$} & \multicolumn{2}{c}{ Seed Yield $\left(\mathrm{kg} \mathrm{ha}^{-1}\right)$} & \multicolumn{2}{c}{1000 Seed Weight $(\mathrm{g})$} \\
\cline { 2 - 5 } & 20 & 2017 & 2018 & 2017 & 2018 \\
\hline \multirow{4}{*}{ Cv. Ulkem } & 35 & $2178.5^{\mathrm{a}}$ & $1463.6^{\mathrm{a}}$ & $183.93^{\mathrm{a}}$ & 160.90 \\
& 50 & $1446.4^{\mathrm{b}}$ & $1045.3^{\mathrm{ab}}$ & $181.44^{\mathrm{ab}}$ & 156.90 \\
& 65 & $1336.3^{\mathrm{bc}}$ & $780.3^{\mathrm{bc}}$ & $174.24^{\mathrm{b}}$ & 154.30 \\
& Mean & $1441.9^{\mathrm{b}}$ & $594.4^{\mathrm{bc}}$ & $179.09^{\mathrm{ab}}$ & 153.85 \\
\cline { 2 - 5 } & 20 & $1600.8^{\mathrm{A}}$ & $970.9^{\mathrm{A}}$ & $179.67^{\mathrm{A}}$ & $156.48^{\mathrm{A}}$ \\
\hline \multirow{5}{*}{ Line H-8 } & 35 & $1223.3^{\mathrm{bc}}$ & $589.9^{\mathrm{bc}}$ & $155.41^{\mathrm{cd}}$ & 147.10 \\
& 50 & $1206.1^{\mathrm{bc}}$ & $524.2^{\mathrm{bc}}$ & $161.17^{\mathrm{c}}$ & 146.40 \\
& 65 & $861.5^{\mathrm{bc}}$ & $447.8^{\mathrm{c}}$ & $168.42^{\mathrm{bc}}$ & 155.70 \\
& Mean & $765.5^{\mathrm{c}}$ & $396.7^{\mathrm{c}}$ & $165.71^{\mathrm{bc}}$ & 153.15 \\
\hline
\end{tabular}

*There is no difference $(\mathrm{P} \leq 0.05)$ amongst the values indicated same letters within the same column.

Table 2. Mature pod ratio, pod and seed numbers of cowpea*

\begin{tabular}{c|ccccccc}
\hline \multirow{2}{*}{ Genotypes } & Row Spacing & \multicolumn{2}{c}{ Mature Pod Ratio $(\%)$} & \multicolumn{2}{c}{ Pod Number/Plant } & \multicolumn{2}{c}{ Seed Number/Pod } \\
\cline { 2 - 7 } & $(\mathrm{cm})$ & 2017 & 2018 & 2017 & 2018 & 2017 & 2018 \\
\hline \multirow{4}{*}{ Cv. Ulkem } & 20 & $85.8^{\mathrm{a}}$ & $60.3^{\mathrm{a}}$ & $5.66^{\mathrm{b}}$ & $9.50^{\mathrm{c}}$ & $11.20^{\mathrm{ab}}$ & 8.90 \\
& 35 & $81.7^{\mathrm{ab}}$ & $56.7^{\mathrm{ab}}$ & $10.00^{\mathrm{ab}}$ & $11.75^{\mathrm{bc}}$ & $11.13^{\mathrm{ab}}$ & 11.20 \\
& 50 & $78.5^{\mathrm{ab}}$ & $54.3^{\mathrm{ab}}$ & $15.00^{\mathrm{a}}$ & $11.35^{\mathrm{bc}}$ & $8.80^{\mathrm{b}}$ & 10.00 \\
& 65 & $77.7^{\mathrm{ab}}$ & $49.9^{\mathrm{ab}}$ & $9.33^{\mathrm{ab}}$ & $10.85^{\mathrm{bc}}$ & $12.43^{\mathrm{a}}$ & 9.60 \\
\cline { 2 - 8 } & Mean & $80.9^{\mathrm{a}}$ & $55.3^{\mathrm{a}}$ & $10.00^{\mathrm{A}}$ & 10.86 & 10.89 & 9.93 \\
\hline \multirow{5}{*}{ Line H-8 } & 20 & $79.1^{\mathrm{ab}}$ & $43.7^{\mathrm{ab}}$ & $7.00^{\mathrm{ab}}$ & $16.25^{\mathrm{a}}$ & $10.47^{\mathrm{ab}}$ & 11.50 \\
& 35 & $76.9^{\mathrm{ab}}$ & $42.2^{\mathrm{ab}}$ & $6.00^{\mathrm{b}}$ & $13.85^{\mathrm{ab}}$ & $12.02^{\mathrm{a}}$ & 11.40 \\
& 50 & $70.0^{\mathrm{ab}}$ & $39.9^{\mathrm{bc}}$ & $7.00^{\mathrm{ab}}$ & $9.80^{\mathrm{c}}$ & $10.13^{\mathrm{ab}}$ & 8.00 \\
& 65 & $65.7^{\mathrm{b}}$ & $30.0^{\mathrm{c}}$ & $9.66^{\mathrm{ab}}$ & $10.60^{\mathrm{bc}}$ & $11.67^{\mathrm{a}}$ & 8.70 \\
\hline & Mean & $72.9^{\mathrm{B}}$ & $38.9^{\mathrm{B}}$ & $7.41^{\mathrm{B}}$ & 12.63 & 11.07 & 9.90 \\
\hline
\end{tabular}

*There is no difference $(\mathrm{P} \leq 0.05)$ amongst the values indicated same letters within the same column.

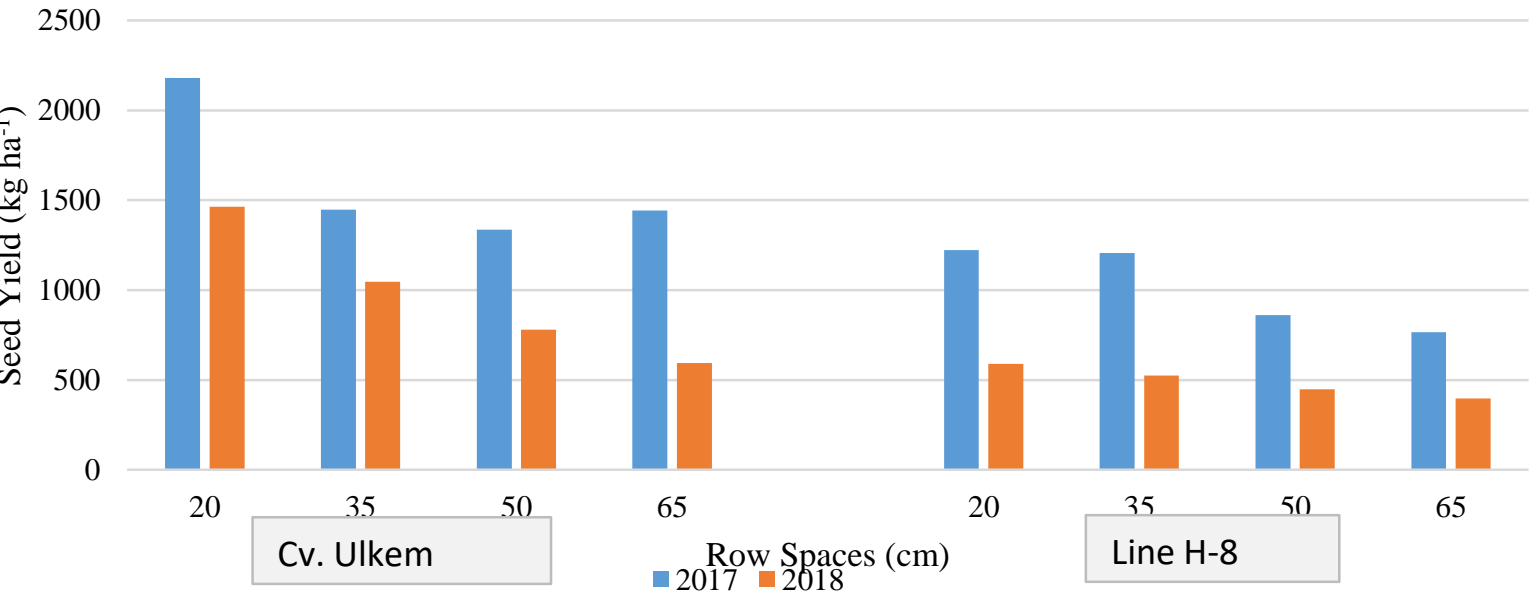

Figure 3. Seed yield of cowpea in 2017-2018 


\section{Conclusions}

In the future farming system, importance of cowpea known as resistant to high temperature and drought is likely to increase due to changing climatic conditions. It can be said that double crop system is risky for seed production because of earlier autumn rainfall and high humidity. Despite everything, someone wants to produce cowpea seed in double crop production system, $\mathrm{Cv}$. Ulkem can be recommended to grown with $20 \mathrm{~cm}$ row spacing in central black Sea region of Turkey.

\section{Acknowledgment}

2017 data of this study was used as Master Thesis by Husein Abdulkadir Omar

\section{References}

Ali Y, Aslam Z, Hussain F, Shakur A. 2004. Genotype and environmental interaction in cowpea (Vigna unguiculata L.) for yield and disease resistance. Int. J. Environ. Sci. \& Tech.1:119.

Atış İ. 2000. Hatay Ekolojik Koşullarında İkinci Ürün Olarak Hasıl Amacıyla Yetiştirilebilecek Börülce (Vigna sinensis L.) Ekotiplerinin Verim Ve Verim Unsurlarının Belirlenmesi. Yüksek Lisan Tezi, Mustafa Kemal Üniversitesi, Fen Bilimleri Enstitüsü, 63s, Hatay.

Ayan İ, Mut H, Basaran U, Acar Z, Onal Asci O. 2012. Forage potential of cowpea (Vigna unguiculata L. Walp.) Turkish Journal of Field Crops, 17(2): 135 - 138.

Basaran U, Ayan I, Acar Z, Mut H, Onal Asci O. 2011. Seed yield and agronomic parameters of cowpea (Vigna unguiculata L.) genotypes grown in the Black Sea Region of Turkey. African Journal of Biotechnology, 10(62): 1346113464.
Dadson RB, Hashem FM, Javaid I, Joshi J, Allen AL, Devine TE. 2005. Effect of water stress on the yield of cowpea (Vigna unguiculata L. Walp.) genotypes in the Delmarva region of the United States. Journal of Agronomy and Crop Science, 191(3), 210-217.

Gülümser A, Tosun F, Bozoğlu H. 1989. Samsun Ekolojik Şartlarında Börülce Yetiştirilmesi Üzerinde Bir Araştırma. O.M.Ü. Ziraat Fakültesi Dergisi, Cilt: 4, No: 1-2, 49-65s, Samsun.

Ismail AM, Hall AE. 2000. Semidwarf and standard-height cowpea response to row spacing in different environment. Crop. Sci., 40:1618-1623.

Kuykendall LD, Hashem FM, Dadson RB, Elkan GK. 2000 Nitrogen fixation. In: J. Lederberg, ed. Encyclopedia of Microbiology, vol. 3, pp. 329-404. Academic Press, New York.

Martins LMV, Xavier GR, Rangel FW, Ribeiro JRA, Neves MCP, Morgado LB, Rumjanek NG. 2003. Contribution of biological nitrogen fixation to cowpea: a strategy for improving grain yield in the semi-arid region of Brazil. Biology and fertility of soils, 38(6), 333-339.

Ozturan Y, Gulumser A. 2004. The effects Of Raw Spacing and Nitrogen Fertilization on Yield and Yield Components Of Cowpea (Vigna unguiculata L. Walp.) Journal of Agriculture Faculty, OMU., 19(3): 41-49.

Ozturk D. 2010. Ordu Ekolojik Koșullarında Yetiștirilebilecek Börülce (Vigna sinensis L.) Ekotiplerinin Bazı Fizyolojik ve Morfolojik Özellikleri ile Verim ve Verim Öğelerinin Belirlenmesi. Ordu Üniversitesi Fen Bilimleri Enstitüsü, Yüksek Lisans Tezi S: 82, Ordu.

Singh BB, Ajeigbe HA, Tarawali SA, Fernandez-Rivera S, Abubakar M. 2003. Improving the Production and Utilization of Cowpea as Food and Fodder. Field Crops Res. 84:169. 